\author{
Małgorzata DYMYT ${ }^{1}$ \\ Tomasz DYMYT ${ }^{2}$
}

\title{
E-HEALTH AS A TOOL FOR STRENGTHENING THE ROLE OF A PATIENT IN THE PROCESS OF PROVIDING HEALTH SERVICES
}

\begin{abstract}
The development of information and communication technologies has contributed to the emergence of e-health, the sphere of digital activity, related to support for prevention, diagnosis, treatment, monitoring and health management. The patient's involvement in the process of providing health services becomes an important factor conditioning the effectiveness of treatment. A particularly important role of e-health tools is the creation of opportunities to involve patients in the treatment process, increasing their knowledge, personalising and individualising medical care to obtain, strengthening their role in the decision-making process, which on the whole enhances the position of patients. The range of health-enhancing activities that can be carried out using e-health tools is wide and includes the transfer of information, its collection, analysis, processing to support decision-making processes, health education, and furthermore, training of medical personnel and management with administrative aspects. The purpose of the article is to try to identify the possibilities of supporting the process of providing health services through the use of e-health tools. The article consists of three main parts. The first part describes the role of the patient in the process of providing services, including such concepts as subject patient empowerment, patient-centred medicine and personalised medicine. Next, the characterization of the essence and forms of e-health was made. The last part consists of an attempt to identify conditions, possibilities, areas of information application and communication technologies in the health care system. The final conclusions address the challenges faced by health systems and their participants to ensure the effective use of e-health tools in shaping the relationship between patients and healthcare professionals.
\end{abstract}

Keywords: e-health, health services, mobile health, telemedicine, e-patient, patient-centered care, patient empowerment.

\footnotetext{
${ }^{1}$ Małgorzata Dymyt, PhD, Department of Management, General Tadeusz Kościuszko Military University of Land Forces, Wroclaw, Poland; e-mail: malgorzata.dymyt@awl.edu.pl (corresponding author). ORCID: 0000-0002-8238-6917.

Dr Małgorzata Dymyt, Wydział Zarządzania, Akademia Wojsk Lądowych imienia generała Tadeusza Kościuszki, Wrocław, email: malgorzata.dymyt@awl.edu.pl (autor korespondencyjny). ORCID: 0000-0002-8238-6917.

2 Tomasz Dymyt, MSc, Chief Executive Officer, Provincial Hospital Centre of the Jelenia Góra Valley.

Mgr Tomasz Dymyt, dyrektor naczelny Wojewódzkiego Centrum Szpitalnego Kotliny Jeleniogórskiej w Jeleniej Górze. ORCID: 0000-0002-5228-053X.
} 


\section{INTRODUCTION}

Health is a social good that is important for the socio-economic development of the state and a significant and desirable value in the individual dimension. According to the definition of the World Health Organization "health is a state of complete physical, mental and social well-being and not merely the absence of disease or infirmity" 3 . The challenge facing every state is the need to shape a health care system capable of satisfying the health needs of citizens by ensuring availability and high quality of health services.

The range of factors affecting health is wide, as it includes environmental factors and personal determinants, such as: the social and economic environment, the physical environment, and the person's individual characteristics and behaviours. In particular, determinants of health can be as follows: income and social status, education, physical environment (safe water and clean air, healthy workplaces, safe houses, communities and roads all contribute to good health), employment and working conditions, social support networks, culture or else genetic inheritance. They all play a part in determining lifespan, healthiness and the likelihood of developing certain illnesses, personal behaviour and coping skills. Furthermore, balanced eating, keeping active, smoking, drinking, gender (men and women suffer from different types of diseases at different ages) and how we deal with life's stresses and challenges - all affect health, health services access and use of services that prevent and treat diseases influencing health ${ }^{4}$.

This means that all participants of the system are responsible for health at the state, institutional level and patients themselves. This requires active cooperation of all system participants in the process of shaping and delivering health services, adapted to the changing health needs and opportunities, resulting from the progress of medical knowledge and technology development. The attitude and involvement of the patient in the process of providing health services become important factors, conditioning the effectiveness of treatment. Therefore, it is important to act at the systemic and institutional level aimed at educating, promoting and encouraging the involvement of patients. In this context, the ideas of strengthening the role of the patient, patient empowerment, patient-centred care and personalised medicine are an important challenge for the health care system. The development of intelligent healthcare means the necessity to use new technologies for communication between medical staff and patients, educating, and supporting all phases of the treatment process. The following research questions can be formulated: how new technologies can support strengthening the role of the patient in the process of ensuring the implementation of health needs, providing health services, furthermore, what opportunities they create for the development of the idea of patient's focused medicine.

The aim of the article is to describe the role of the patient in the process of providing health services, including the ideas such as: empowerment of the patient, patient-centred medicine, personalised medicine. Will also be characterised the essence, conditions and forms of e-health with an attempt to identify areas of application of information and communication technologies in health services. To implement the adopted objective, the method of analysis and criticism of the literature (desk research) as well as the method of analysing documents, legal acts and reports and statistical data were used. The study is conceptual

\footnotetext{
${ }^{3}$ http://www.who.int/about/mission/en/ (accessed: 3.05.2018).

${ }^{4}$ http://www.who.int/hia/evidence/doh/en/ (accessed: 10.05.2018).
} 
and based on in-depth review of literature and documents, focused on the analysis of modern trends in the development of e-health services and tools.

\section{THE ROLE OF THE PATIENT IN THE PROCESS OF PROVIDING HEALTH SERVICES}

One of the fundamental activities in the process of providing health services is efficient communication between medical staff and patients. Relations between participants of the health service have a diverse, multi-faceted character. In order to characterize the health care services, it is necessary to analyze the scope and purpose of activities as well as the nature and conditions of relations between the participants (patient-medical staff relationships). The scope of the health service should be considered widely, taking into account not only the content itself, the activities within the service, but also the entire process of its provision. The health service is therefore complex and covers all activities consisting in providing access to health care, shaping the service potential, communication, pro-health information and educational activities. In legal terms, health services include "actions to preserve, rescue, restore or improve health and other medical activities resulting from the treatment process or separate provisions regulating the principles of their execution"5. Running a service activity in the area of health is a professional one and requires compliance with a number of formal requirements regarding the qualifications of medical personnel and the powers of the healthcare provider. This means the necessity to apply the given methodology of the health service provision (i.e. a health procedure), that is a description of the manner in which the benefit is provided or a procedure schedule ${ }^{6}$. The health service is a qualitative and quantitative standard consisting of activities, materials and devices (fixed assets) necessary to achieve the assumed goal and includes medical services implemented in the field of medicine and pharmaceutical services implemented in the field of pharmacy?

The specificity of health services, however, manifests itself in terms of such features as: intangibility and lack of guarantee of the health service effectiveness, psychological complexity of the process, constant interaction between the doctor and the patient, the necessity of good communication between the doctor and the patient that is conducive to building trust, a small possibility of differentiating services, dependence of the effectiveness and quality of the health service on the patient's state of health ${ }^{8}$. It can be assumed that the relationship between the patient and the medical staff has a significant impact on the quality and availability of health services. Patients, reporting health needs, expect professional, safe services taking into account their individual circumstances. Ensuring the quality of health services requires the orientation of service activities on the patient, his specific needs and respective position. Among the approaches that accept the role of the patient in the process of providing health services, empowerment patient, patient-centered medicine, and personalized medicine can be distinguished. According to the World Health Organization, in the

\footnotetext{
${ }^{5}$ Ustawa o działalności leczniczej z dnia 15 kwietnia 2011 r. (Dz.U. z 2011 r., nr 112, poz. 654 ze zm.), art. 2, ust. 1, pkt 10 .

${ }^{6}$ https://www.osoz.pl/osoz/web/osoz-cms/definicje (accessed: 10.05.2018).

${ }^{7}$ Ibidem.

${ }^{8}$ A. Bukowska-Piestrzyńska, Marketing ustug zdrowotnych. Od budowania wizerunku placówki do zadowolenia klientów, Warszawa 2009, p. 17-18.
} 
system dimension, one of key characteristics of good service delivery is quality, the provision of which requires effective and safe actions, centred on the patient's needs and given in a timely fashion ${ }^{9}$. WHO indicates the following features of person-centredness: health services are organized around the person, not the disease or the financing, users perceive health services to be responsive and acceptable to them, there is participation from the target population in service delivery design and assessment, patients are partners in their own health care ${ }^{10}$.

The essence of the concept of person-centred medicine is to provide patients with good experiences, including such aspects as: respecting people's values and putting people at the center of care, taking into account their preferences and expressed needs. This approach is based on coordinated and integrated care, which includes: working together to make sure there is good communication, information and education, making sure people are physically comfortable and safe, emotional support, involving family and friends, making sure there is continuity between and within service and ultimately, making sure people have access to appropriate care when they need $\mathrm{it}^{11}$. These activities are very broad, diverse, have a holistic and subjective character in the approach to patients and their health needs. The main goal of these actions is communication that builds lasting relationships. Mc. Beach and T. Inui proposed interesting relationship-centered care (RCC) model, in which all participants appreciate the importance of their relationships with one another, based on the following principles: relationships should include the personhood of participants, important elements of these relationships are the affects and emotions, all relations have the character of mutual influence and creating and maintaining genuine relationships has a moral value ${ }^{12}$.

The concept of focusing on the patient is not only shaping good relationships but also improves proper communication between participants of the health service. An individual approach, taking into account specific, individual social and biological determinants, is related to the possibilities of personalising medical services. Personalised medicine is defined as a multidisciplinary, dynamically developing field in which the patient's treatment is carried out in an individualised way, thanks to the use of modern diagnostic methods, mainly molecular biology methods ${ }^{13}$. Personalised medicine focuses on patients as well as on the mechanisms of health and disease prevention, and includes, among others, such activities as: searching for drugs compatible with individual sensitivity, anticipating the development of disease changes, adjusting nutrition and lifestyle to the state of disease ${ }^{14}$.

The condition for the development of personalised medicine is the focus on the patient (with his/her human attributes) and not only on the disease itself and optimal active parti-

${ }^{9}$ Monitoring the building blocks of health systems: a handbook of indicators and their measurement strategies, section 1, Health service delivery, WHO 2010, p. 3. http://www.who.int/healthinfo/systems/WHO_MBHSS_2010_section1_web.pdf (accessed: 11.05.2018).

${ }_{10}$ Monitoring the building blocks of health systems..., p. 3, http://www.who.int/healthinfo/systems/WHO_MBHSS_2010_section1_web.pdf (accessed: 11.05.2018).

11 What is person-centred care and why is it important?, Health Innovation Network South London, March 2016, s. 2, https://healthinnovationnetwork.com/system/ckeditor_assets/attachments/41/ what_is_person-centred_care_and_why_is_it_important.pdf (accessed: 8.06.2018).

12 MC. Beach, T. Inui, Relationship-centered care - A constructive reframing, "Journal of General Internal Medicine" 2006, 21, s. 53.

13 A. Fronczak (red.), Medycyna personalizowana. Mity, fakty, rekomendacje, Łódź 2016, s. 78.

${ }^{14}$ M. Pasowicz, Medycyna nowej generacji [in:] M. Pasowicz (red.), Zdrowie i medycyna - wyzwania przyszłości, Kraków 2013, p. 86 i n. 
cipation of patients ${ }^{15}$. This requires the patient to be involved in identifying changes, reactions, symptoms, needs and appropriate information transfer. The patient becomes an active participant in the process of providing a health service. It is therefore necessary to strengthen the role of patients, making them active, even involved participants in the health service. Getting a patient to play an active role is a complex task, requiring the inclusion of a number of conditions. Among the factors affecting patient involvement, the following are distinguished: acceptance of the new role of the patient, the level of health awareness and knowledge about health, belief in one's own abilities, the type of decision to be taken, the rank of problems to which the decisions apply, the type of illness and accompanying diseases, age, gender, socio-economic status, ethnicity, using the methods of alternative medicine and specialisation of a healthcare staff member ${ }^{16}$.

Therefore, a comprehensive approach to the patient involvement and patient empowerment is necessary. The concept of patient empowerment is characterised by six components, such as: communication (facilitating patient communications with health professionals, education and health literacy), information (access to personal medical information furthers patients' control in the management of their health), good-quality personalised health information, self-care (support and engaging in health management in many routine activities of daily living e.g. nutrition, physical activity), decision aids (preparing and helping patients for making informed decisions about their care options and support services e.g. patient organization) and contact with fellow patients (sharing experiences and information, supporting other patients) ${ }^{17}$.

To ensure the provision of patient-oriented health services, process-based operation is required, starting from recognising patient's needs. The following fundamental principles of the concept are distinguished: getting to know the patient as a person and recognising their individuality, seeing the patient as an expert about their own health and care, sharing power and responsibility, taking a holistic approach to assessing people's needs and providing care, including families where appropriate, making sure that services are accessible, flexible and easy to navigate, looking at people's whole experience of care to promote coordination and continuity, making sure that the physical, cultural and psychosocial environment of health services supports person-centred care, making sure that staff are supportive, well trained in communication and striving to put people at the centre of their care ${ }^{18}$.

Summing up, it can be stated that the concept of person-centred care is based on effective communication, enabling shaping mutual relations between participants of the health service. The patient must therefore have knowledge about his role, activities, and capabilities and have access to the tools necessary for constant communication.

${ }^{15}$ L. Chouchane, R. Mamtani, A. Dallol, J.I. Sheikh, Personalized Medicine: A Patient-Centered Paradigm, "Journal of Translational Medicine", 2011 9:206, DOI: 10.1186/1479-5876-9-206, p. 2-3.

16 Y. Longtin, H. Sax, L. L. Leape, S. E. Sheridan, L. Donaldson, D. Pittet, Zaangażowanie pacjenta: stan wiedzy $i$ wptyw na bezpieczeństwo opieki, „Medycyna po dyplomie” 2010, Vol. 19, No. 6, p. 118.

${ }^{17}$ L. Alpay, P. van der Boog, A. Dumaij, An empowerment-based approach to developing innovative e-health tools for self-management, "Health Informatics Journal" 2011, 17(4), DOI: 10.1177/ 1460458211420089, http://jhi.sagepub.com/content/17/4/247 (accessed: 8.06.2018), p. 248.

18 What is person-centred care and why is it important?..., p. 4, 


\section{THE ESSENCE, GOALS AND FORMS OF E-HEALTH}

The development of digital technologies has contributed to the progress in the delivery of health services. Digital innovations have created opportunities for changes in the processes of communication and management of relations between participants in the healthcare system. E-health in a broad sense means the use of information and communication technologies (ICT) for health ${ }^{19}$.

World Health Organization defines e-health as "the cost-effective and secure use of information communication technologies (ICT) in support of health and health related fields, including health-care services, health surveillance, health literature, and health education, knowledge and research" 20 . The scope of activities related to the use of information and communication technologies is wide and concerns all participants and stakeholders of the health care system. According to the definition of the European Commission "digital health and care refers to tools and services that use information and communication technologies (ICTs) to improve prevention, diagnosis, treatment, monitoring and management of health and lifestyle. Digital health and care has the potential to innovate and improve access to care, quality of care, and to increase the overall efficiency of the health sector" 21 .

E-health tools include exchange of information and data between patients and healthcare providers, hospitals, health professionals and entities responsible for information networks; electronic medical records; telemedicine services; portable devices for patient monitoring, scheduling software, robots used in surgery and basic research in the field of the virtual model of human physiology ${ }^{22}$. According to G. Eysenbach e-health is more than a set of tools and technical development, "but also a state-of-mind, a way of thinking, an attitude, and a commitment for networked, global thinking, to improve health care locally, regionally, and worldwide by using information and communication technology"23. E-health is a phenomenon closely related to the growing possibilities of digital support for satisfying health needs.

The main forms of e-health include mobile health and telemedicine. One of the rapidly developing forms of e-health is a mobile health ( $m$-health); the development of mobile telephony has created new opportunities for communication between healthcare service providers and patients. It is estimated that the number of mobile phone users in 2018 will reach the level of 5.135 billion $^{24}$. In 2017 there were 325.000 health apps (health \& fitness and medical apps) available on all major app stores ${ }^{25}$.

M-health covers "medical and public health practice supported by mobile devices, such as mobile phones, patient monitoring devices, personal digital assistants (PDAs), and other

19 http://www.who.int/ehealth/en/ (accessed: 5.05.2018).

${ }^{20}$ Global diffusion of eHealth: making universal health coverage achievable. Report of the third global survey on eHealth, World Health Organization, 2016, p. 11, http://www.who.int/goe/publications/global_diffusion/en/(accessed: 5.05.2018).

${ }^{21} \mathrm{https}: / /$ ec.europa.eu/health/ehealth/overview_en (accessed: 6.04.2018).

${ }^{22} \mathrm{https}: / /$ ec.europa.eu/health/ehealth/overview_pl (accessed: 6.04.2018).

${ }^{23}$ G. Eysenbach, What is e-health?, "Journal of Medical Internet Research" 2001, Vol. 3, iss. 2, e20, doi:10.2196/jmir.3.2.e20.

${ }^{24} \mathrm{https}: / /$ wearesocial.com/uk/blog/2018/01/global-digital-report-2018 (accessed: 15.06.2018).

25 mHealth Economics 2017 - Current Status and Future Trends in Mobile Health, Research2Guidance 2017, s. 10, https://research2guidance.com/product/mhealth-economics-2017-current-statusand-future-trends-in-mobile-health/ (accessed 12.05.2018). 
wireless devices ${ }^{26}$. M-health includes applications such as lifestyle and wellbeing apps that may connect to medical devices or sensors (e.g. bracelets or watches) as well as personal guidance systems, health information and medication reminders provided by SMS and wirelessly provided telemedicine ${ }^{27}$. World Health Organization identifies the following types of mobile health, within the following dimensions of communication ${ }^{28}$ :

- communication between individuals and health services, health call centres/ health care telephone helplines, emergency toll-free telephone services,

- communication between health services: treatment adherence, reminder to attend appointments, community mobilization/health promotion campaigns,

- consultation between health care professionals: mobile telehealth,

- intersectoral communication in emergencies, emergency management systems,

- health monitoring and surveillance, health surveys, surveillance, patient monitoring,

- access to information and education for health care professionals: access to information, resources, databases and tools, clinical decision support systems, electronic patient information, m-learning.

The next group of tools is telemedicine identified with telehealth. Telemedicine is defined as "the delivery of health care services, where distance is a critical factor, by all health care professionals using information and communication technologies for the exchange of valid information for diagnosis, treatment and prevention of disease and injuries, research and evaluation, and for the continuing education of health care providers, all in the interests of advancing the health of individuals and their communities" ${ }^{29}$. Telemedicine solutions include ${ }^{30}$ :

- tele-diagnostics - diagnosis is made on the basis of medical data sent via information and communications technology (ICT networks, computer files), for example: telediagnosis in teleradiology (description of the study by the teleradiology center) or cardiology (tele-electrocardiography),

- telemonitoring - a patient with a chronic illness is equipped with a device that measures vital parameters at specified intervals, and the measurement results are sent to the telemonitoring centre, then specialised algorithms analyse influencing results, and in emergency situations, alert the doctor on duty, who intervenes,

- teleconsultation - video-conversation between an internist, a patient and a specialist physician (or team of doctors of various specialties) to gather an interview from the patient and even conduct an examination,

- tele-rehabilitation - providing instructional materials on rehabilitation and video conferences, during which the therapist controls the quality and correctness of the rehabilitation exercises performed,

- tele-teaching - trainings, lectures and presentations, online platforms and portals transmitting the online course of innovative operations,

${ }^{26}$ GREEN PAPER on mobile Health ("mHealth"), European Commission, Brussels, 10.4.2014, $\operatorname{COM}(2014) 219$ final, p. 3.

27 Ibidem, p. 3.

${ }^{28}$ Global diffusion of eHealth..., p. 29.

${ }^{29}$ Telemedicine. Opportunities and developments in Member States Report on the second global survey on eHealth Global Observatory for eHealth series, Vol. 2, WHO 2010, p. 9.

${ }^{30}$ M. Jankowski, A. Klimczak-Wieczorek, M. Kloc, M. Matuszewski, J. Rozum, Telemedycyna w Polsce możliwości i szanse rozwoju, Warszawa 2016, p. 5. 
- tele-surgery - operations "at a distance", the surgeon remotely controls the surgical robot, which according to its commands and movements performs the various stages of the operation.

The multitude of digital solutions in healthcare means that the beneficiaries of the use of e-health tools are patients, medical personnel, administration and management staff of health service providers, as well as the entire healthcare system. E-health includes interaction between patients and health care providers, data transfer between institutions or between partners, between patients and healthcare professionals that aim to improve citizens' health, increase the availability of health services, efficiency and productivity in delivering health care and the economic and social value of health ${ }^{31}$. The scope of health improvement activities that can be carried out using the e-health tools is wide and includes: information transfer, its collection, analysis, processing to support decision-making processes, health education, training of medical personnel, and management of administrative activities.

\section{THE APPLICATION OF E-HEALTH TOOLS IN THE DEVELOPMENT OF PATIENT INVOLVEMENT}

Access to knowledge about the state of your health, the possibility of obtaining reliable, comprehensive information on treatment methods, healthy behaviours, healthy lifestyle are the foundation in providing patient-centered healthcare. One of the main obstacles to increasing patient involvement is low patient health awareness and lack of knowledge related to health ${ }^{32}$. For this reason, it is crucial to consider the key activities in the patient empowerment concept, described in Table 1.

For the development of personalised medicine, it is necessary not only to provide information but also to collect and analyse it by creating secure databases including personalised data (electronic patient records). The role of information systems is therefore not only to enable the analysis of data on the patient's health status and the decision-making process of medical staff, but also to make the knowledge available to patients, thanks to which they become much more involved in monitoring their own health ${ }^{33}$. Technological solutions covering e-health tools (including mobile applications) create opportunities for acquiring, collecting, processing information and sharing them with doctors and other patients, making the patient more aware, educated, motivated and involved in the treatment process. J.L. Monteagudo and $\mathrm{O}$. Moreno identified five big categories of e-health patient empowerment applications (existing in EU countries), such as ${ }^{34}$ :

1. information production - tools and supports for information and educational materials in electronic formats (electronic publishing is more timely, dynamic and less expensive than traditional paper based publishing),

31 eHealth Action Plan 2012-2020 - Innovative healthcare for the 21 st century, Communication from the Commission to The European Parliament, The Council, The European Economic And Social Committee And The Committee Of The Regions, Brussels, 6.12.2012, p. 3.

32 Y. Longtin, H. Sax, L.L. Leape, S.E. Sheridan, L. Donaldson, D. Pittet, Zaangażowanie pacjenta..., p. 124

33 A. Fronczak (red.), Medycyna personalizowana. Mity, fakty, rekomendacje, Łódź 2016, s. 119.

${ }^{34}$ J.L. Monteagudo, O. Moreno, e-Health for Patient Empowerment in Europe..., s. 43-44. 
2. telephone communication services - applications and tools supported by generic telephonic services such as call centers, voice mail, audio conferencing, etc. using fixed and mobile telephonic networks,

3. data communication services (no healthcare specific) - applications constructed using e-mail, mobile SMS, web pages and internet interactive services (can be simple passive information of administrative nature, to complex health interactive services or virtual communities support),

4. ICT healthcare management - specific applications and services as for example, electronic personal records (EPR), electronic prescription and electronic appointment systems,

5. personal health platforms to support complex processes of care delivery, based on partnership of different actors and the active collaboration of the patient (constructed using or interacting with e-health applications of the above categories, i.e. of systems for self-care management and chronic care).

Table 1. Key activities in patient empowerment concept

\begin{tabular}{|l|l|}
\hline \multicolumn{1}{|c|}{ Activities } & \multicolumn{1}{c|}{ Objectives } \\
\hline $\begin{array}{l}\text { Consumer Communication } \\
\text { with health agents and } \\
\text { carers }\end{array}$ & $\begin{array}{l}\text { Facilitating consumer communication with the healthcare agents, particu- } \\
\text { larly with physicians. }\end{array}$ \\
\hline $\begin{array}{l}\text { Consumer Health } \\
\text { Information access }\end{array}$ & $\begin{array}{l}\text { Improving citizen's access to appropriate health information and their ca- } \\
\text { pacity to use it effectively. }\end{array}$ \\
\hline $\begin{array}{l}\text { Consumer Health Educa- } \\
\text { tion process }\end{array}$ & $\begin{array}{l}\text { Encouraging the use of healthcare resources, active participation in activi- } \\
\text { ties promoting health (promoting knowledge about the health care system, } \\
\text { health insurance/provision options, etc.). }\end{array}$ \\
\hline $\begin{array}{l}\text { Consumer Decision mak- } \\
\text { ing aids }\end{array}$ & $\begin{array}{l}\text { Preparing patients for decision making about professional care options by } \\
\text { providing information on the options and outcomes, relevant to the per- } \\
\text { son's health status. }\end{array}$ \\
\hline $\begin{array}{l}\text { Consumer Self-care } \\
\text { support }\end{array}$ & $\begin{array}{l}\text { Supporting patients through virtual communities operating in the network, } \\
\text { primarily in the field of self-education and self-responsibility, encourage } \\
\text { patients' initiative, and provide members with an opportunity to help } \\
\text { others, sharing experiences in the area of health. }\end{array}$ \\
\hline $\begin{array}{l}\text { Chronic Care integrated } \\
\text { services support }\end{array}$ & $\begin{array}{l}\text { Active partnership between healthcare professional and patient (education } \\
\text { and support for self-care). Implementing a disease management approach, } \\
\text { aimed to co-ordinate services across the health and social care sectors in } \\
\text { order to deliver ongoing care. }\end{array}$ \\
\hline
\end{tabular}

Source: own work on basis: J.L. Monteagudo, O. Moreno, e-Health for Patient Empowerment in Europe, Madrid, July 2007, p. 33-39.

To increase the involvement of patients through the active use of e-health tools, it is necessary to encourage patients through the medical staff, making them aware of the benefits and threats. E-health should be treated comprehensively. According to G. Eysenbach the prefix "e" in the word e-health should be understood broadly as: efficiency, enhancing quality of care, evidence based (effectiveness and efficiency should be proven by rigorous scientific evaluation), empowerment of consumers and patients (patient-centered medicine), enabling evidence-based patient choice, encouragement of a new relationship between the patient and health professional, towards a true partnership, where decisions are 
made in a shared manner, education of physicians through online sources (continuing medical education) and consumers (health education, tailored preventive information for consumers), enabling information exchange and communication in a standardized way between health care establishments, extending the scope of health care beyond its conventional boundaries, ethics, equity ensuring equitable access for all to infrastructure and networks, easy-to-use, entertaining and exciting (it should definitely exist) ${ }^{35}$.

The development of information and communication technologies contributes to the formation of a new category of patients such as e-patients. In broad terms, it can be assumed that an e-patient is a person who - regardless of his or her health condition - uses information and communication technologies when using health services ${ }^{36}$. According to Eurostat, $51 \%$ of individuals aged 16 to 74 use the internet to search for health-related information (injury, disease, nutrition, improving health, etc.) ${ }^{37}$.

The idea of an e-patient can refer to four different concepts: having the ability to manage your own health, be enabled to make choices regarding self-care, including their choices respected, having the right to choose a team of health professionals who are involved in the treatment, engagement in their own healthcare ${ }^{38}$. The term e-patient includes the patients themselves, the sick who seek information helpful in meeting their own health needs, as well as their friends and family members who use the internet on their behalf ${ }^{39}$. The characteristic feature of an e-patient is the awareness of the importance of seeking information, the pursuit of gaining and deepening knowledge about health. The access to information makes patients become enabled, empowered, engaged and able to play more active role, participate fully in shared decision-making, regarding their medical care, and take personal responsibility for self managing their illness and care ${ }^{40}$.

One of the important elements of the concept of strengthening the patient through access to information is the issue of sharing knowledge with doctors and other patients. Providing information about the current state of health supports medical personnel in deciding on the way of further medical care. However, sharing information can have a wider range and go beyond the patient-doctor relationship. Using social media, information on experience in the field of medical care, ways of solving health problems can be provided to other patients and specialists using the idea of a crowdsourcing. Crowdsourcing is believed to revolutionise health care by creating, gathering and passing on 'collective wisdom' to a wide range of interested people around the world, in particular in the area of information gathering,

${ }^{35}$ G. Eysenbach, What is e-health?...

${ }^{36}$ M. Czerwińska, Specyfika zachowań e-pacjentów w Internecie, „Roczniki Kolegium Analiz Ekonomicznych" 2015, nr 38, Warszawa, p. 346.

${ }^{37} \mathrm{http}: / /$ ec.europa.eu/eurostat/tgm/table.do?tab=table\&init=1\&language=en\&pcode=tin00101 (acessed: 15.06.2018).

${ }^{38}$ European e-patient. Report 2015. An annual report about the everyday life of e-patients, People Who Global, Madrid, April 2016, p. 93.

${ }^{39}$ T. Ferguson, E-patients: how they can help us heal healthcare, The e-Patient Scholars Editorial Team, San Francisco, March, 2007, s. II, https://participatorymedicine.org/e-Patient_White_Paper_with_Afterword.pdf (accessed: 15.06.2018).

${ }^{40}$ M. Hegdekar, The emergence of e-patients: Role of internet and social media in Participatory Medicine, Research Paper based on lectures at the Medlink or Workshop Conferences at Nottingham University, December 2013, April 2014, p. 2, https://medlink-uk.net/wp-content/uploads/2014/09/HegdekarM.pdf (accessed: 1.07.2018). 
making decisions and helping to solve even the most difficult medical issues quickly and accurately ${ }^{41}$.

E-health tools contribute to the shaping of the smart health care which is characterised by the following features: appropriate treatments are delivered at the appropriate time, in the appropriate place, for the appropriate patient, specialists use technology to more accurately diagnose and treat illness and deliver care, patient data is in one, easily accessible place, all care delivery stakeholders across the ecosystem effectively and efficiently communicate and use information, the correct individuals do the correct work, patients are informed and actively involved in their treatment plan, new, cost-effective delivery models bring health care to places and people that don't have it, efficiency improves; waste declines $^{42}$. E-health tools create opportunities for creating relationships between all participants of the healthcare system. These benefits will only be felt if all participants are active, use the tools available, and stimulate contacts in the virtual space.

\section{CONCLUSIONS}

The development of digital technologies implies changes in all spheres of life, including the health care system. Technological solutions in the field of information and communication find a wide application in health services, satisfying healthy needs. This applies to contacts between patients with entities providing health services, medical staff, or between patients and other patients. The key challenge for the development of e-health services and tools is to focus them on the patients and their needs (patient-centered care), subordinating the processes of digitalisation in health services to the idea of strengthening the role of the patient.

Particularly important role of e-health tools is to create opportunities to involve patients in the treatment process, increase patient knowledge, personalise, individualise medical care, strengthen their role in the decision-making process, which leads to the empowerment of patients. Despite the many perceived benefits of e-health tools, there are still many barriers that limit their use, among which should be mentioned such as: lack of awareness of, and confidence in e-health solutions among patients, citizens and healthcare professionals, lack of interoperability between e-health solutions, limited large-scale evidence of the costeffectiveness of e-health tools and services, lack of legal clarity for health and wellbeing mobile applications and the lack of transparency regarding the utilisation of data collected by such applications, inadequate or fragmented legal frameworks including the lack of reimbursement schemes for e-health services, high start-up costs involved in setting up e-health systems and regional differences in accessing ICT services, limited access in deprived areas ${ }^{43}$.

In the face of such limitations, it should be recognised that a comprehensive approach to the development and implementation of e-health tools is indispensable. The challenges related to this concern both the state, the system level, entities that provide health services

${ }^{41}$ M. Hegdekar, The emergence of e-patient..., p. 9.

422018 Global health care outlook - The evolution of smart health care, Deloitt, 2018, p. 4, https://www2.deloitte.com/content/dam/Deloitte/global/Documents/Life-Sciences-HealthCare/gx-lshc-hc-outlook-2018.pdf (accessed: 5.05.2018).

43 eHealth Action Plan 2012-2020 - Innovative healthcare for the 21 st century..., p. 5. 
and medical personnel, as well as patients themselves, their associations, formal and informal social groups. The role of the state is to create rules for the functioning and use of e-health tools, taking into account patient safety and data on their health status, securing access to infrastructure, promoting the idea of patient involvement, educating the public in the field of health issues and the possibility of using modern technologies in health services. It seems, however, that the main responsibility for strengthening the role of the patient is on the side of health care providers and medical staff. Their task should be to strive to create personalised relationships based on trust, commitment, and care for the well-being of the patient. It is important to use modern technologies not only to support administrative services (registration, e-prescriptions) but also to communicate, to shape effective relationships between the patient and the doctor. Patients also need to see the benefits of using e-health tools, they must have a sense of security and opportunities to participate in decision-making, and above all, they should accept their new role (as e-patients, smart patients) in the health care delivery process.

The review of literature allows us to conclude that the issue of e-health in the context of strengthening the role of the patient, in world literature, is the subject of a broad, interdisciplinary discussion. Also in Poland an increasing discussion in the area of e-health services and tools takes place, however the aspect of strengthening the role of the patient in Polish literature is not sufficiently described. It seems that patient orientation of e-health services is particularly important in the context of the digitisation of the health care system in Poland.

\section{REFERENCES}

1. Beach MC., Inui T., Relationship-centered care - A constructive reframing, "Journal of General Internal Medicine" 2006/21.

2. Bukowska-Piestrzyńska A., Marketing ustug zdrowotnych. Od budowania wizerunku placówki do zadowolenia klientów, CeDeWu, Warszawa 2009.

3. Chouchane L., Mamtani R., Dallol A., Sheikh J.I., Personalized Medicine: A Patient-Centered Paradigm, "Journal of Translational Medicine" 2011, 9:206, DOI:10.1186/14795876-9-206.

4. Czerwińska M., Specyfika zachowań e-pacjentów w Internecie, „Roczniki Kolegium Analiz Ekonomicznych”, nr 38, Szkoła Główna Handlowa, Warszawa 2015.

5. eHealth Action Plan 2012-2020 - Innovative healthcare for the 21st century, Communication from the Commission to The European Parliament, The Council, The European Economic And Social Committee And The Committee Of The Regions, Brussels, 6.12.2012.

6. European e-patient. Report 2015. An annual report about the everyday life of e-patients, People Who Global, Madrid, April 2016.

7. Eysenbach G., What is e-health?, "Journal Of Medical Internet Research" 2001, Vol. 3, iss. 2, e20, DOI:10.2196/jmir.3.2.e20.

8. Fronczak A. (red.), Medycyna personalizowana. Mity, fakty, rekomendacje, Plexus s.c., Łódź 2016.

9. GREEN PAPER on mobile Health ("mHealth"), European Commission, Brussels, 10.4.2014.

10. Jankowski M., Klimczak-Wieczorek A., Kloc M., Matuszewski M., Rozum J., Telemedycyna w Polsce możliwości i szanse rozwoju, Warszawa 2016. 
11. Longtin Y., Sax H., Leape L.L., Sheridan S.E., Donaldson L., Pittet D., Zaangażowanie pacjenta: stan wiedzy $i$ wptyw na bezpieczeństwo opieki, „Medycyna po dyplomie” 2010, Vol. 19, No. 6.

12. Pasowicz M., Medycyna nowej generacji [in]: Pasowicz M. (red.), Zdrowie i medycyna wyzwania przyszłości, Oficyna Wydawnicza AFM, Kraków 2013, ss. 85-95.

13. Telemedicine. Opportunities and developments in Member States Report on the second global survey on eHealth Global Observatory for eHealth series - Vol. 2, WHO 2010.

\section{LEGAL ACTS}

1. Ustawa o działalności leczniczej z dnia 15 kwietnia 2011 r. o działalności leczniczej (Dz.U. z 2011, nr 112 poz. 654 ze zm.).

\section{INTERNET SOURCES}

1. 2018 Global health care outlook - The evolution of smart health care, Deloitt, 2018, https://www2.deloitte.com/content/dam/Deloitte/global/Documents/Life-Sciences-HealthCare/gx-lshc-hc-outlook-2018.pdf (accessed: 5.05.2018).

2. Alpay L., van der Boog P., Dumaij A., An empowerment-based approach to developing innovative e-health tools for self-management, "Health Informatics Journal" 17(4), 2011, pp. 247-255, DOI: 10.1177/1460458211420089, http://jhi.sagepub.com/content/17/4/247 (accessed: 8.06.2018).

3. Ferguson T., E-patients: how they can help us heal healthcare, The e-Patient Scholars Editorial Team, San Francisco, March, 2007, https://participatorymedicine.org/e-Patient_ White_Paper_with_Afterword.pdf (accessed: 15.06.2018).

4. Global diffusion of eHealth: making universal health coverage achievable. Report of the third global survey on eHealth, World Health Organization 2016, http://www.who. int/goe/publications/global_diffusion/en/ (accessed: 5.05.2018).

5. Hegdekar M., The emergence of e-patients: Role of internet and social media in Participatory Medicine, Research Paper based on lectures at the Medlink or Workshop Conferences at Nottingham University, December 2013 - April 2014, https://medlink-uk.net/wp-content/uploads/2014/09/HegdekarM.pdf (accessed: 1.07.2018).

6. mHealth Economics 2017 - Current Status and Future Trends in Mobile Health, Research2Guidance 2017, https://research2guidance.com/product/mhealth-economics-2017current-status-and-future-trends-in-mobile-health/ (accessed 12.05.2018).

7. Monitoring the building blocks of health systems: a handbook of indicators and their measurement strategies, section 1, Health service delivery, WHO 2010. http://www.who. int/healthinfo/systems/WHO_MBHSS_2010_section1_web.pdf (accessed: 11.05.2018).

8. Monteagudo J.L., Moreno O., e-Health for Patient Empowerment in Europe, Madrid, July 2007, https://www.researchgate.net/publication/264273560 (accessed: 6.06.2018).

9. What is person-centred care and why is it important?, Health Innovation Network South London, March 2016, https://healthinnovationnetwork.com/system/ckeditor_assets/attachments/41/what_is_person-centred_care_and_why_is_it_important.pdf (accessed: 8.06. 2018).

10. http://ec.europa.eu/eurostat/tgm/table.do?tab=table \&init=1\&language=en $\&$ pcode $=$ tin00101 (accessed: 15.06.2018). 
11. http://www.who.int/about/mission/en/ (accessed: 3.05.2018)

12. http://www.who.int/ehealth/en/ (accessed: 5.05.2018)

13. http://www.who.int/hia/evidence/doh/en/ (accessed: 10.05.2018)

14. https://ec.europa.eu/health/ehealth/overview_en_(accessed: 6.04.2018).

15. https://ec.europa.eu/health/ehealth/overview_pl (accessed: 6.04.2018).

16. https://wearesocial.com/uk/blog/2018/01/global-digital-report-2018 (accessed: 15.06 . 2018).

17. https://www.osoz.pl/osoz/web/osoz-cms/definicje (accessed: 10.05.2018)

\title{
E-ZDROWIE JAKO NARZEDZIE WZMACNIANIA ROLI PACJENTA W PROCESIE ŚWIADCZENIA USŁUG ZDROWOTNYCH
}

\begin{abstract}
Rozwój technologii informacyjno-komunikacyjnych przyczynił się do powstania e-zdrowia, sfery aktywności cyfrowej, odnoszącej się do wspierania profilaktyki, diagnostyki, leczenia, monitorowania i zarządzania zdrowiem. Zaangażowanie pacjenta w proces świadczenia usług zdrowotnych staje się ważnym czynnikiem warunkującym skuteczność leczenia. Szczególnie istotną rolą narzędzi e-zdrowia jest tworzenie możliwości angażowania pacjentów w proces leczenia, zwiększania wiedzy o pacjencie, personalizacji, indywidualizacji opieki medycznej, wzmacniania ich roli w procesie podejmowania decyzji, co prowadzi do wzmocnienia pozycji pacjentów. Zakres działań na rzecz poprawy zdrowia, które mogą być prowadzone przy użyciu narzędzi e-zdrowia, jest szeroki i obejmuje przekazywanie informacji, ich gromadzenie, analizę, przetwarzanie w celu wspierania procesów decyzyjnych, edukację zdrowotną, szkolenie personelu medycznego i zarządzanie aspektami administracyjnymi. Celem artykułu jest próba identyfikacji możliwości wspierania procesu świadczenia usług zdrowotnych przez wykorzystanie narzędzi e-zdrowia. Artykuł składa się z trzech głównych części. W pierwszej części opisano rolę pacjenta w procesie świadczenia usług, z uwzględnieniem takich koncepcji jak: upodmiotowienie pacjenta, medycyna skoncentrowana na pacjencie i medycyna spersonalizowana. Następnie charakteryzowano istotę i formy e-zdrowia. W ostatniej części dokonano próby zidentyfikowania uwarunkowań, możliwość i obszarów zastosowania technologii informacyjnych i komunikacyjnych w opiece zdrowotnej. Wnioski końcowe dotyczą wyzwań, przed jakimi stoją systemy opieki zdrowotnej i ich uczestnicy dla zapewnienia skutecznego wykorzystania narzędzi e-zdrowia w kształtowaniu relacji pomiędzy pacjentami i personelem medycznym.
\end{abstract}

Słowa kluczowe: e-zdrowie, usługi zdrowotne, mobilne zdrowie, telemedycyna, e-pacjent, medycyna skoncentrowana na pacjencie, wzmocnienie roli pacjenta.

DOI: $10.7862 /$ rz.2018.mmr.40

Tekst złożono do redakcji: sierpień 2018 r.

Tekst przyjęto do druku: grudzień 2018 r. 